Portland State University

PDXScholar

Applied Linguistics Faculty Publications and

Presentations

Applied Linguistics

$1-1-2011$

\title{
Gendering French in Tunisia: language ideologies and nationalism
}

Keith Walters

Portland State University

Follow this and additional works at: https://pdxscholar.library.pdx.edu/ling_fac

Part of the Anthropological Linguistics and Sociolinguistics Commons

Let us know how access to this document benefits you.

\section{Citation Details}

Walters, K. (2011). Gendering French in Tunisia: language ideologies and nationalism. International Journal Of The Sociology Of Language, 2011(211), 83-111.

This Article is brought to you for free and open access. It has been accepted for inclusion in Applied Linguistics Faculty Publications and Presentations by an authorized administrator of PDXScholar. Please contact us if we can make this document more accessible: pdxscholar@pdx.edu. 


\section{Gendering French in Tunisia: language ideologies and nationalism*}

KEITH WALTERS

Abstract

This paper seeks to describe and account for a common ideology among Tunisians and North Africans more broadly that associates the use of French with women, thereby symbolically associating the use of Arabic with men. In this regard, the use of French can be said to be "gendered" there. In an effort to historicize this phenomenon, I sketch the social history of French in Tunisia, particularly in regards to the access female and male Tunisians would historically have had to it through the institution of schooling. I then consider the different relationships contemporary Tunisian men and women have with French. Finally, I seek to contextualize these relationships in light of other ideologies that are part of Tunisian daily life, particularly notions of "authenticity" and "openness", tropes of many forms of discourse in Tunisia.

Keywords: Tunisia; gender; ideology; Arabic; French; social history of language.

A woman from La Marsa went to the dentist with a cavity. When he told her that he was going to have to give her a local anesthetic, she replied, "Don't you have anything imported?"

\section{Introduction}

This joke, which circulated widely in Tunisia in the mid-1980s, functioned as a form of social critique then, as it would today (cf. Sherzer 2002). ${ }^{1}$ I heard it multiple times, told always by a man. (I, too, am a man, and it is important to acknowledge homosocial patterns of verbal and social interaction, including joke telling, both in the Arab world and in the West.) Each time I heard the 
joke, the teller codeswitched. Such Arabic/French codeswitching is common among Tunisians, especially educated ones; in fact, it is constitutive of Tunisianness in crucial ways. The teller always began in Tunisian Arabic but switched to French for the noun phrase "local anesthetic" before switching back to Arabic and then switching again to French for "imported" — the final word of the joke's punch line and thus a rhetorically marked structural position. ${ }^{2}$

In retelling the joke, most tellers used the French name of the town of La Marsa, historically the most affluent of the northern Tunis suburbs along the Mediterranean coast and still the most chic among them. A few used its Arabic name, [1-marsa], the pronunciation of al-marsa in Tunisian Arabic. Among those who used the French version of the town's name, some rendered it in what we might term "North African French", crucially using an apical [r]. Others pronounced the name in a way that approximated or was identical to what we would expect from a native speaker of Standard French, including use of the uvular $[\mathrm{y}] .{ }^{3}$ (Importantly, because both of these sounds are phonemic in Arabic, all Tunisians can articulate both with equal ease. Therefore, any differences in choice of $r$-variant cannot be linked to ability.)

Some aspects of the joke's social critique are quite obvious while others emerge only in the context of local knowledge. A non-Tunisian can correctly guess that conflicts at play include those related to class and perhaps region as well as what some might term authenticity - the local versus the non-local, self versus other. Those with a knowledge of recent Tunisian history would be aware that during this period, the last years of the rule of Habib Bourguiba, the "father" of the country, the "Supreme Combatant", and its first president (1956-1987), the Tunisian economy was in peril, and few goods of any kind were imported. Hence, access to them represented a particular mark of distinction (Bourdieu 1987).

How can we understand this joke in the contexts in which it was told and retold? What can it teach us about language in Tunisia and more particularly language and gender and even much more abstract issues like language and nationalism? In this article, I seek to address these issues by considering three topics. First, I review what is known about how French came to be in Tunisia and widely used there. Second, I examine how the speaking of French is "gendered", that is the ways in which Tunisian women and men have and have had different relationships with French — its acquisition, norms of use (especially with respect to accent), and motivations for its use. Finally, I examine the linguistic ideologies that have arisen among Tunisians about French, its utility, and its functions in creating Tunisian national identity.

Throughout I am concerned with two aspects of language ideologies: first, the complex ways they are linked to ideologies about other social constructs (e.g., gender, nationalism, and the links between them) and, second, their everydayness, particularly the ways they are reinscribed in countless mundane 
forms such a jokes, proverbs, or often-repeated quips and taken as representations, however problematic, of social reality. Following Irvine, I take language ideologies to be "the cultural system of ideas about social and linguistic relationships, together with their loading of moral and political interests" (Irvine 1989: 285). An understanding of such ideologies is crucial to the project of sociolinguistics and linguistic anthropology because, as Kroskrity aptly stated, "a group's beliefs about language, often unexamined beliefs at that, are typically at the heart of its sense of group identity" (Kroskrity 2004: 511). Hence, in explicating ideologies, we are able to understand the constitutive roles language plays in the identity of social groups, here, Tunisians, and more particularly, Tunisians as men or women, as we gain insight into important aspects of Tunisian culture.

\section{The linguistic situation in contemporary Tunisia and the role of French there}

Tunisia is the most ethnically and religiously homogeneous country of the Arab world. Well over 99\% of the native-born population is Muslim, and over $98 \%$ of the native-born population identifies as Arab. While a few thousand foreigners, most of European origin, and some immigrants - many from North Africa and an increasing number from south of the Sahara - live there, one also finds a small number of native Tunisians who would identify as Berber, most living on the island of Djerba or in the far south of the country, although we have no way of knowing how many of these Tunisians might speak a variety of their heritage language. (Berber was, of course, the indigenous language of North Africa prior to the arrival of the Phoenicians.) There are very few monolingual speakers of Berber, especially among younger people, and any older monolingual speakers are almost assuredly women, adult men having learned Tunisian Arabic as their daily lives brought them in contact with speakers of the language. There are also several very small Jewish communities - again, on the island of Djerba, in Tunis, and in one or two other of the country's smaller cities - with a unique confessional or communal dialect of Tunisian Arabic (Walters 2006). As explained below, the fact that Tunisia has no sizable social minorities, particularly minorities whose identity is indexed by a language other than Tunisian Arabic, helps distinguish the country from its Maghrebian neighbors, Algeria and Morocco, both of which have large minorities whose native language is some variety of Berber.

Despite this social homogeneity, one finds great linguistic diversity. My efforts to represent the broadest outlines of that diversity can be found in Figure 1, a schematic diagram of the Tunisian linguistic situation focusing on languages, language varieties, and language practices generally associated with 


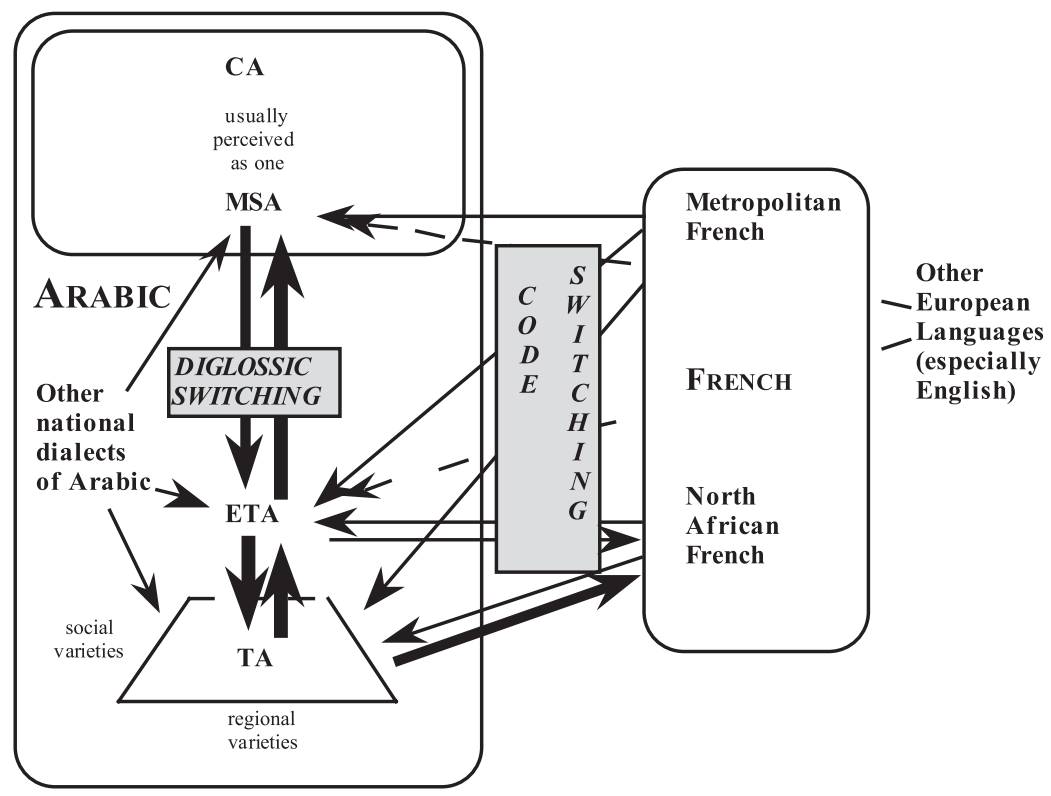

CA

MSA

ETA

TA

Metropolitan French North African French

Codeswitching

Diglossic switching
Classical Arabic: the Arabic of the Qur'an and the Islamic heritage. Modern Standard Arabic: basically, modernized CA, supplemented by the addition of lexical items for new technology and influenced by European languages, especially at the levels of syntax and style. Elevated Tunisian Arabic: Tunisian Arabic with learned borrowings from CA/MSA, spoken by educated Tunisians. A variety that originally began as a register, it has probably become a social (i.e., class) dialect for some, especially those growing up in urban communities in homes where both parents are well educated.

Tunisian Arabic, national dialect of Arabic spoken natively in Tunisia, which incorporates a large number of nativized borrowings from Berber, Italian, and French.

The French of France, especially the variety legitimated by schools. French as it is used in speaking and to some degree writing by most North Africans, for whom it is not a native language. As with most nonnative varieties of a language, it is marked variably at all linguistic levels by traits distinguishing it from the variety taught in France. The most common kind of codeswitching found in Tunisia is what Myers Scotton (1993) has termed "codeswitching as unmarked choice" although all four of the types of switching she delineates occur there. Codeswitching between the High and Low varieties of Arabic within a single speech exchange. Most often, it involves the use of features of MSA, usually lexis or set expressions, when speaking ETA or TA.

Figure 1. Schematic representation of the Tunisian linguistic situation (Walters 1996: 528) 
language contact. In this article, my focus is French and particularly its complex links to Tunisian ideologies of gender and of nationalism. I contend ultimately that only by studying the situation of French in Tunisia can we understand the situation of Arabic or other languages there. By extension, given the multilingual nature of all countries of the modern Arab world, an adequate understanding of them - or of the role of Arabic in them - depends on thinking relationally, i.e., understanding how the languages and language varieties used in each country relate to one another.

Such a move runs contrary to much work on the region, where the research literature generally treats each language hermetically, as if it existed in isolation. One category of exception here would be research, often pedagogical in nature, that focuses on interference from one of the languages present on the other, e.g., Brahim's (1994) treatment of errors in the French of Tunisian university students. Working within the norm-and-deviation paradigm that continues to characterize the teaching of standardized languages, Brahim did not consider the possibility that there exists a conventionalized way of using French structurally influenced by knowledge of Arabic that has come to index North Africanness. From this perspective and in light of the research on language contact, much of what Brahim analyzes can be seen as an emerging regional variety of nonnative French that does not take the speech of Paris as its primary model.

A second category of exception would be research on Arabic that begins with the assumption that the language is under siege, whether the enemy is seen as European languages or as the spoken dialects of Arabic that some argue are contaminating the standardized variety, the fuș $\hbar a$, traditionally associated with writing and formal contexts as described by Ferguson (1959). (See Walters [2007b] for a discussion of the ideologies associated with these positions.) Obviously, both of these exceptional bodies of research are motivated by an obsession with language purism (cf. note 11).

\section{How did French come to Tunisia?}

When asked how French came to Tunisia or how it spread, North Africans and North Africanists will reply quizzically that the French brought it, as if the answer to the question were self evident and perhaps not very interesting. Yet the social history of the language there is, in fact, more complex. Clearly there were groups of speakers of French - perhaps even communities - long before Tunisia became a French colony in 1881. I contend that an understanding of the social history of languages, including French, in Tunisia can help us understand the present sociolinguistic situation of the country and the region in ways that would otherwise be impossible. 
Readers familiar with the research on language in North Africa will surely know that we have the beginnings of such discussions about the social history of Arabic, for example, Massignon's lengthy (1924) article, "Éléments arabes et foyers d'arabisation: Leur rôle dans le monde musulman actuel" and Marçais' (1938) “Comment l'Afrique du Nord a été arabisée." Although each is written from a slightly different perspective much colored by the orientalism of its time, it provides us with insights into how North Africa became arabized to the extent that it is, even today. Further, Massignon's metaphor of "foyer", literally 'fireplace' or 'hearth', with its connotations of physical location, fire, heat, light, nativity, and concentrated focus, ${ }^{4}$ is useful in so far as it encourages us to think in terms of the uses of Arabic, and in this case French, in everyday life, reminding us that Arabic did not spread across the land like a river flooding a plain: it spread hearth to hearth, school to school, register to register, speech act to speech act. French did not spread like a flood either and does not even now.

Let us begin considering the spread of French in Tunisia by asking how widespread knowledge of the language is today. The most recent data available date from 1994..$^{5}$ They present a snapshot of the demographics of Tunisia, however grainy, at that time, looking toward the past with regard to the languages of literacy and education - the variety of Arabic taught in school, French, and English. They tell a story of the sociolinguistic consequences of colonization and independence, of projections of identity at the level of the ruling power at the time (Walters 1999, 2007a, 2011). Tunisian girls began to get access to French — and Modern Standard Arabic and English — to any real degree only after independence in 1956, but by the mid 1990s, Tunisian women had come close to catching up with men. By the mid-1990s, over $96 \%$ of children aged 6-10 were in school, including over $90 \%$ of girls in that age cohort. Especially when one recalls that the mean age in Tunisia is 29, these data likewise demonstrate the extent to which Tunisia is francisée, an extent to which it never was during the colonial period and was not intended to be. ${ }^{6}$

One should also realize that the status of French in Tunisia continues to evolve. Friends of mine there who graduated from high school before independence have high school diplomas that were valid in France as well as Tunisia because the exit exams they took were the same ones students their age in France (as well as in a number of former French colonies) took. French was the medium of instruction in these schools, of course. I have met Tunisians now in their 60s who received what were termed bacs classiques (i.e., classical baccalauréats, "baccalauréat" being the French term for high school diploma); in other words, they studied Latin and Greek in high school but precious little Arabic, and any Modern Standard Arabic they might have studied was taught by a Frenchman using the grammar/translation method. An important fact about education during the colonial period is that from the arrival of "modern 
education" in the nineteenth century, there were several different kinds of schools: colonial schools that taught European and Tunisian children in French; the elite Collège Sadiki in Tunis (Sraïb n.d.), which provided a fully bilingual education for young boys who would become the political elite of independent Tunisia; les écoles franco-arabes, a system of colonial schools designed to teach Tunisians, generally boys, French and some Arabic; and schools set up by religious groups or communities, especially the Catholic Church, the Alliance Israélite Universelle, and, during a certain period, the London Society for Spread of Christianity amongst the Jews (Dornier 2000; Perkins 2004; Walters 2011). Not surprisingly, each type of school attracted a different segment of the population.

In contrast, after independence, Tunisia, like many developing countries, made universal education a goal, and nearly all Tunisians who attended school studied in institutions controlled by the Tunisian government. For many reasons, including a lack of appropriate materials and trained teachers as well as political will, French remained the primary language of instruction in these schools until the 1980s (cf. Abbasi 2005; Daoud 2001). When I taught English as a foreign language in a rural Tunisian school in the mid-1970s, French was used as the medium of instruction for all subjects except religion and Tunisian history. Thus, success in science or math was predicated on mastery of French, and many of the teachers with whom I taught were French coopérants civils or militaires, roughly contractors working for the French government as part of aid to a former French colony or men fulfilling their military service requirement by teaching in a former French colony. Because of this situation, the first-generation high-school students I taught interacted almost daily with native speakers of French in and out of school even as they had the opportunity to interact with native speakers of English. Tunisian education was completed Tunisified by the late 70s, and the foreign teachers disappeared. Also gone were native speaker models and occasions to speak with native speakers. When a Tunisian student meets his or her Tunisian teacher of French in the market today, if they speak at all, it will almost surely be in Arabic.

Today, Arabic is the language of instruction in all pre-university education in the country. French is taught as a subject beginning in elementary school; it is used as a medium of instruction only in certain subjects at the university level (generally science, technology, engineering, and math). Its history there and the role it has traditionally played and continues to play as a marker of elite status ensure that it will remain an important part of the symbolic linguistic economy and the linguistic ecology of the country. Yet while it remains a second (rather than foreign) language in the perceptions of many Tunisians, its presence and roles in public life continue to change. Certainly, it is widely used, especially in areas that attract large numbers of tourists. Yet by the 1990s, government forms that had earlier been printed in Arabic and French appeared 
only in Arabic, and by the turn of the century, political banners and other forms of public announcements were often posted only in Arabic, a marked shift from earlier years.

However, as noted, the continued arabization of spaces and contexts earlier reserved for French or for French and Arabic does not signal an end to the symbolic value of French. Increasingly, the issue is not whether one knows French (after all, nearly everyone has studied French at school) but having mastered it to a high degree. Obviously, gaining such a degree of mastery represents a particular challenge since French is no longer a medium of instruction but simply taught as a subject in contexts where there may be few, if any, native models of language use in daily interactions. At the same time, Frenchlanguage media - television, radio, movies, print, and electronic media - are widely available. (It is worth noting that some of the French-language media are produced by Tunisians in Tunisia as well.) Thus, the earlier census data and these facts about the changing role of French in education and society more broadly help us begin to speculate about some of the reasons why Tunisian men and women of each generation have and have had such different relationships with each of their languages.

Another important aspect of the social history of French in Tunisia, one necessary for understanding the place of French in the country today, relates to where French speakers were during the colonial period. Whereas contemporary Tunisia is, as noted, ethnically and religiously quite homogenous, such has not always been the case, a fact with sociolinguistic consequences. Table 1 , for example, gives us data on school enrollment in 1905. (The schools included are "modern", that is European, schools, where French was the medium of instruction; Qur'anic schools for Tunisian Muslim boys are not included nor are Talmudic schools for Tunisian or European Jewish boys.) Obviously, Muslim children were in the minority in modern schools; what is relevant for our discussion is the diversity of the population.

Although Europeans made up a more or less consistent percentage of the population from 1921 until 1956, 7\%-8\%, they were not equally spread across the protectorate. Census data from the period divide the population into Muslims; local Jews - those who did not have European citizenship, however obtained; and Europeans. (Thus, the category "European" included European Christians, nearly all Catholics, as well as Jews from European countries.) Those familiar with Tunisia and Tunisian history will not be surprised to hear that the largest percentages of Europeans and Jews were to be found in Tunis, the capital. Indeed, $53 \%$ of the Tunis population was listed as European and $9 \%$ as Jewish. Thus, some $38 \%$ of the Tunis population was Arab - or "Muslim", as the census listed it. Elsewhere, in seventeen of the conscriptions, or regions, Tunisian Muslims made up more than $90 \%$ of the population (and $95 \%$ or more in twelve of those) and over $85 \%$ in the two others. 
Gendering French in Tunisia 91

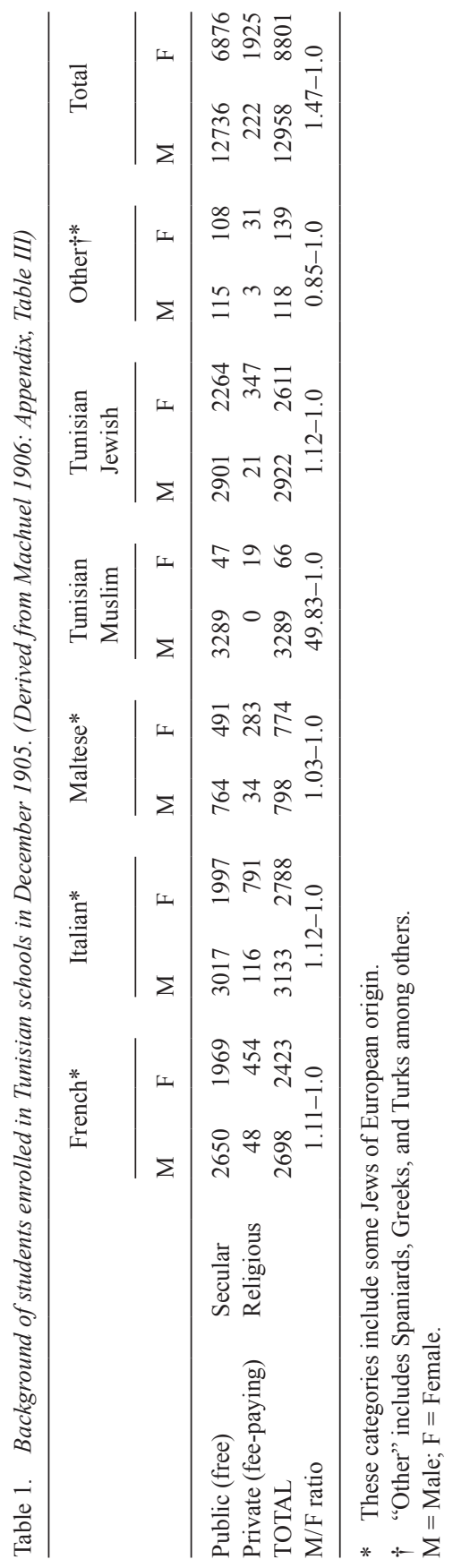


Also worth noting is the role played by naturalization during this period, whereby people who were not born French became French during their lifetime. (Table 17.4 in Walters [2011] provides information from the 1948 census on naturalizations from 1881, the beginning of French rule, until the date of that census.) The data on naturalizations by citizens of at least twenty-three different countries remind us that even among Europeans, many speakers of French were almost assuredly nonnative speakers of the language, as would have been the Tunisian speakers of French. Striking is the large number of naturalizations involving those born Italian and those born Tunisian Jews. Throughout the nineteenth and into the twentieth centuries, Italians represented the largest population of Europeans in Tunisia; the French became the majority only in 1920 thanks to the large numbers of Italians who became French citizens. Of course, Tunisian Jews represented a diverse community including those who had been there for centuries, arrivals from Spain, and Portugal following the Inquisition, and later waves of Jewish immigrants from Italy, and they were very differently positioned by the colonial power than were Tunisian Muslims. The diversity of the Jewish community had consequences for its dealings first with the Ottoman Empire and later with the colonizing power.

I pay special attention to the situation of Tunisian Jews here because despite their liminal status, the colonial power set up conditions that encouraged assimilation, including the learning and use of French. ${ }^{7}$ As the data in Walters (2011) demonstrate, there were over six Jewish naturalizations for each Muslim naturalization among Tunisians. Such processes of naturalization continued until the end of the colonial period, when a series of internal and external events encouraged Tunisian Jews and people who identified as European to leave Tunisia, helping create the ethnically and religiously homogeneous country we find today.

These sources of information - the nature of the population of Tunis during the colonial period, the location of Europeans, especially the French, at that time, and the questions of naturalization - give us some insight into Tunisia's linguistic past and potentially its present. Certainly, the European presence, especially that of the French, was significant, not only because of the power it represented but also because of the numbers of people involved and the variety of French that was likely legitimated and rewarded.

This European and more particularly French presence in Tunis would have assuredly created many occasions for Europeans speaking French to one another and to Tunisians, occasions that had not existed before and do not exist now. Further, the situation created a context where speakers from many linguistic backgrounds would have used French as their lingua franca. (Likewise, there are certainly occasions for using or hearing French today that did not exist then: for example, radio came to Tunisia in 1938). It is also worth noting 
that the colonial census reports that a large number of Europeans spoke Tunisian Arabic to varying degrees. In fact, the French colonial government rewarded with extra pay those of its members who spoke Arabic, a practice that we can easily associate with a desire to understand and control the colonized. These facts remind us that earlier Tunisian speech communities, and especially those in and around Tunis, were extremely complex in terms of the varying repertoires of their members, exactly the sorts of repertoires used in just the sorts of contexts that might encourage intra- and intersentential codeswitching of the sort associated with Tunis today.

Indeed, the use of French in Tunisia today and especially the frequent use of Arabic/French codeswitching are associated mostly with Tunis, les tunisois - residents of Tunis, and more particularly, les tunisoises — women from Tunis. One hears both French and codeswitching far less in other places even smaller cities - in Tunisia, and those who do not live in the capital city often comment on these practices in very negative ways. For example, just over a decade ago, a Tunisian friend, a university professor who has a $\mathrm{PhD}$ from a US university, lived an hour or so outside Tunis near the community where he had grown up but commuted to the capital city every work day. When I asked him why, he explained that he and his wife lived where they did so that they could be near family - an important concern for all Tunisians, but he also stated that he did not want his daughters growing up codeswitching like the girls in Tunis do. As he explained, it was not who he and his wife were or who they wanted their daughters to become. Importantly, this man codeswitches with frequency in his daily life; thus, the relevant issue is one of degree, something that is lost in ideologizations that link language and identity categories, as explained below. As this conversation demonstrates, one of the many things frequent use of French and codeswitching can index is an association with urban life, urbanity, and whatever else Tunis may index for Tunisians inside or outside the city.

Having offered some details about how French came to Tunisia, details that are not included in any of the usual discussions of language in Tunisia, and historicized some of the links between French and Tunis, the capital, in particular, let me now turn to the question of gendering French.

\section{How is French gendered in Tunisia?}

Ask any group of Tunisians, and they'll tell you in a heartbeat that Tunisian women are better at French than Tunisian men. On further questioning, they'll explain that, by this statement, they are making any or all of several claims: that Tunisian women are more interested in mastering French than Tunisian men, that they are more likely to use it and use it more often in codeswitching 
involving Arabic than are Tunisian men, and that a Tunisian woman's accent when speaking French is more likely to approximate that of the French legitimated in France than that of a Tunisian man. Even people with no training in linguistics will mention or more likely perform the use of the uvular French /y/ rather than apical /r/ associated with the French of Tunisian men, as was noted in the discussion of the joke that opened this article. Importantly, people treat these claims as social facts about Tunisian society. The limited existing empirical research as well as my five year's experience living in Tunisia since 1975 and dealing with Tunisians there and in the United States convinces me that Tunisians are likely correct in their claims.

I wish to argue that at any complete account of these social facts lies in the different histories women and men in Tunisia have had with respect to formal education and the languages in which that education would have been delivered. Prior to the advent of modern education - always in a European language - in the mid-nineteenth century, Tunisian boys who received an education attended Qur'anic or Talmudic schools, depending on their religion (cf. Perkins 2004). In contrast, aside from the case of elite Tunisian women who would have been tutored by governesses, Tunisian girls and women first had access to educational opportunities when schools were created for the daughters of the colonizers. Such opportunities for education were seized upon by European, Tunisian Jewish, and Tunisian Muslim families to varying extents and for varying reasons (Bakalti 1996; Walters 2007a; Zangar 1997). Further, as Bakalti noted, when education in Arabic was later offered to girls, who were permitted advanced Qur'anic education only in 1944, it was limited in scope and content. By the 1950s, for example, the few young women receiving higher education at the Jaam ${ }^{c}$ a El-Zitouna, the Zitouna Mosque, a center of Islamic learning since its founding in $698 \mathrm{CE}$, complained that their education included no French and did not prepare them for life in the modern world. Thus, colonial schooling became a significant foyer de francisation for Tunisian females at a time when other opportunities were quite limited. Here, their status, historically liminal in some regards, parallels in some ways that of Tunisian Jews. When paths to achievement or advancement open to majority or dominant groups are for any reason closed to members of marginalized groups, these latter often find or create alternative routes, frequently transgressing boundaries of one sort or another - at least in the eyes of the dominant culture, and such transgressions may well become the basis for social change (cf. Walters 2011).

As the earlier discussion of census data made clear, however, schooling has not been a foyer de francisation for women alone. Today, it remains the primary such foyer for all Tunisians, as noted above. To the extent that Western sociolinguistic theorizing is valid, we might claim that for a number of reasons, Tunisian women have seized upon French as one index of gender in the sense 
that Ochs (1992) used the notion. Clearly, it points to a constellation of acts, activities, and stances about many issues, including modern — in contrast to traditional - constructions of womanhood and gender relations generally linked in complex ways with France and the West more broadly.

Further, as Walters (1996) explained, mastery of a language or language variety is in some ways essentially different from many other sorts of symbolic capital because using — literally embodying — a language or language variety is a matter of Bourdieu's habitus - predispositions acquired through a complex process of socialization. In other words, as a symbolic commodity and source of capital, the ability to use a language cannot be directly bought or sold. Particularly since, as Irvine and Gal (2000) pointed out, in an inflated interactional economy, one must strive for something more "conspicuously special", we might ask what could be more conspicuously special in Tunisia than French spoken as in Paris - or as not spoken by many Tunisians? (Significantly, however, the precise social meanings of the conspicuousness and the specialness of such French shifted across the twentieth century and continue to shift in the twenty-first.)

As noted, during the colonial period, European, Tunisian Jewish, and Tunisian Muslim families offered their daughters education to different degrees and for different reasons. Among those differences was the nature of marriage within the culture. Certainly for Tunisian Muslims and Tunisian Jews, marriage - especially at that time - would assuredly have been conceived as a relationship between families, and a daughter who had received a "European" education could compete in a very different set of markets from one who had received a traditional Qur'anic education or no education at all. Even today, a Tunisian woman who speaks French well embodies her achievements, advertising them each time she speaks. Thus, she may be able to marry up, or the young man marrying her might be able to improve his own status because of his wife's linguistic abilities. To the extent she is successful, she improves the symbolic and economic status of the family. In Walters (2011), I detailed aspects of how this process worked in the Jewish community of Tunis in the early twentieth century, where language shift and loss occurred as the community moved from speaking the Jewish variety of Tunisian Arabic to speaking French, and the marriage market was an important aspect of language shift.

\section{Questions of language ideology}

Given this information about French, its distribution in the Tunisian population, its history in the country, and some of its social meanings, I turn to another significant question, that of language ideologies about French and thus 
Speaking French

Speaking French "without an accent"

Use of the "French" pronunciation of $/ \mathrm{r} /$

(Frequent) codeswitching involving French

Figure 2. The iconic relationships between language practices associated with French and gender among Tunisians

other languages in Tunisia, using three processes that work together to create and perpetuate language ideologies as discussed by Irvine and Gal (2002). The first of these is iconization, whereby "the sign relationship between linguistic features (or varieties) and the social images" with which it is linked comes to function as an icon. The relationship may be "historical, contingent, or conventional", but it is treated as essential or "inherent" (Irvine and Gal 2002: 37). As implied above, the use of French, the use of the uvular $/ \mathrm{y} /$, and frequent use of intrasentential Arabic/French codeswitching have all come to have an iconic relationship with women, as illustrated in Figure 2.

In fact, as Ochs (1992) would remind us, the steps involved in the ideological process are more complex than the figure illustrates. The practices noted in the figure can be said more properly to index femininity (or minimally, not masculinity), at least in certain contexts and in some general sense in Tunisian society, which, in turn, is linked to the category "women". (Thus, predictably, the heterosexuality of Tunisian males who speak French a great deal, speak it with a "French" accent, and/or codeswitch frequently is sometimes called into question. $)^{8}$

The second of these processes is fractal recursivity, whereby "an opposition, salient at some level of relationship" (Irvine and Gal 2002: 38), is projected onto another. Tunisians, for example, in conversation and in academic analysis acknowledge that both men and women use French, that both women and men use the uvular /y/ when speaking the language, even admitting that there is intraspeaker variation with regard to this variable in many cases, and that both men and women codeswitch using Arabic and French, as discussed in the analysis of the joke that opened this article. Yet, the dominant language ideology projects intragroup and intraspeaker variation onto intergroup categories of gender linked in complex ways to bodily morphology. Importantly, this gendered distinction then becomes mapped onto dichotomies from other cultural fields. We can illustrate these processes as in Figure 3.

The third process, erasure, as its name implies, involves "simplifying the sociolinguistic field, render[ing] some persons or activities (or sociolinguistic phenomena) invisible" (Irvine and Gal 2000: 38). In the Tunisian case, all the variability within groups and speakers gets reduced, coded as gender difference while other sorts of difference - for example, urbanness versus ruralness or matters of social class - disappear. Likewise, everything that is not associ- 
Social Reality:

Intraspeaker (within-speaker variation) involving various bilingual practices:

i) use of Arabic and French

ii) speaking French with accents ranging from "very Tunisian" to "very French"

iii) pronouncing the $r$ when speaking French using an apical or uvular variant

iv) Arabic/French codeswitching

Ideology:

Intergroup variation (between groups): Men: Women

Figure 3. Cases of fractal recursivity with respect to French language practices among Tunisians

Intergroup variation (between groups):

Men: Women $\longleftrightarrow$ French

Intraspeaker (within speaker variation): various bilingual practices

i) use of Arabic and French

ii) speaking French with accents ranging from "very Tunisian" to "very French"

iii) pronouncing the $r$ when speaking French using an apical or uvular variant

iv) codeswitching

Social-class differences

Urban/rural differences

History

Figure 4. The processes of erasure that gender French in Tunisia

ated with maleness and Arabic becomes coded as female and French. We can illustrate these processes in Figure 4.

As noted, such symbolic work is decidedly ahistorical, and, significantly, it parallels a key component of the creation of nationalism. As Ernest Renan, philosopher and theorist of nationalism, a topic to which we turn in the next section of the paper, famously remarked in 1882 "L'oubli, et je dirai même l'erreur historique, sont un facteur essentiel de la création d'une nation" [Forgetting and I would go so far as to say historical error are an essential factor in the creation of a nation]. ${ }^{9}$

Let us examine these ideologies at work by considering a passage from the writings of Mahmoud Dhaouadi, a Canadian-trained Tunisian who has written about language from the perspective of sociology or social psychology. In several articles (Dhaouadi 1984, n.d.a,n.d.b) about the speech of Tunisian women, Dhaouadi has commented on what is likely the greater propensity of Tunisian women than Tunisian men to engage in codeswitching involving French. ${ }^{10}$ Like many Tunisian academics, he refers to such codeswitching as francoarabe, by which he and others using the term seem to have in mind what Myers Scotton $(1990,1993)$ would term "codeswitching as unmarked choice" of the sort found among the elite in many postcolonial settings, i.e., intrasentential 
codeswitching engaged in by social peers (if only for the interaction); the meaning of the switching is carried by the overall patterns of switches in contrast to the other categories of codeswitching she delineates. ${ }^{11}$

In commenting on this practice of codeswitching in his publications and manuscripts, Dhaouadi has acknowledged that as individuals and as groups, Tunisian women and men use French, that their choice of accent is gradient, ranging from very "Arab" or North African to very French or "Parisian", and that they vary in their choice of ' $r$ ' depending on life experience and present context. Yet, his underlying complaint - and it is indeed a complaint - has been that women violate some unspoken norm about the appropriate use of French or choice or accent or ' $r$ ' in that the frequency of their behavior exceeds that of Tunisian men. Relying on early post-colonial theorists like Memmi (1957), a Tunisian Jew who has long lived in France, and Trudgill's (1972) arguments about gender and language, Dhaouadi argued that Tunisian women codeswitch and use the uvular variant of $/ \mathrm{r} /,[\mathrm{y}]$, because they suffer from a "double contempt" - because of their status as the former subjects of colonization, because of the continuing conditions for women in their own countries, and because of the status of their unstandardized native language, Tunisian Arabic. Given the poverty of their situation, in a sense, they blindly imitate the former colonizer or do their best to. For example, Dhaouadi has commented:

Le Maghrébin (homme et femme) est d'abord infériorisé par son ancien colonisateur (l'effet colonial). En second lieu, la femme maghrébine, surtout éduquée, se sent humiliée dans le contexte moderne par les conditions qui prévalent encore dans sa propre société. Troisièmement, le dialecte arabe que parle couramment la majorité de la population souffre d'un statut inférieur par rapport au français et à l'arabe classique!

[The North African, male and female, is first made inferior by his or her former colonizer (the colonial effect). In second place, the North African woman, especially if educated, feels humiliated in modern contexts by the conditions that continue to prevail in her own society. Third, dialectal Arabic, which is spoken by the majority of the population, suffers from an inferior status by comparison with French or Classical Arabic.]

(Dhaouadi 1984: 94; cited by Trabelsi 1991: 94)

This specific passage is of interest for at least two reasons. First, as is evident from the citation of the French original, Dhaouadi's analysis has, in fact, been quoted by other Tunisian academics, in this case, by Chedia Trabelsi, a Tunisian woman. Following up on his comments, Trabelsi noted:

Cette déclaration est certes exagérée si on pense à tous les Maghrébins, mais elle est assez fidèle en ce qui concerne la tunisoise éduquée et jeune.

[This claim is certainly exaggerated if one considers all North Africans but it is true enough with respect to young, educated women from Tunis.]

(Trabelsi 1991: 94) 


\author{
Superior : Inferior \\ (Tunisian) Men : ((Educated)Tunisian) Women \\ France : Tunisia \\ Standard language : Dialect \\ (French, Classical Arabic) : (Tunisian Arabic)
}

Figure 5. Dichotomies that gender French in Tunisia (Cf. Dhaouadi 1984)

In other words, Dhaouadi's comments cannot be said to be extraordinary in any sense, nor can they simply be attributed to his being male. We might note that Trabelsi did acknowledge the complicating factor of urban versus rural status, but she did not question his basic claims that gender French in complex ways.

A second reason I find this passage especially interesting is that it sets up a series of explicit comparisons that become analogies, a common analytical move in the creation or analysis of ideologies of any kind. In Figure 5, I present these comparisons and link them as Dhaouadi indirectly did.

Such dichotomous analogical chains are a key component of ideological thinking generally and can frequently be found in discussions where language ideologies are at play. ${ }^{12}$ In this set of analogies, we see examples of all three of the processes discussed by Irvine and Gal (2000). First, we see iconization, where a language - French, aspects of French such as accent or even the use of the $/ \mathrm{y} /$, or, I might add, a linguistic practice, codeswitching — is taken, to use Irvine and Gal's words, to "depict or display a social group's inherent nature or essence" (Irvine and Gal 2000: 37), in this case, that of Tunisian women, the behavior of men needing no explanation. Second, we find fractal recursivity because a salient opposition at the one level - variable linguistic behavior within the individual or the group - is projected onto intergroup difference, the behavior of males and females. The opposition is further mapped on the distinction between standard and dialect, that between the former colonial power and the colony, and an assessment of moral value - superior versus inferior. Such multiple mappings of phenomena that are otherwise unrelated, including assessments of moral value, again characterize ideological thinking generally. Finally, as implied, there is strong evidence of erasure because variability is erased and difference essentialized. Thus, from Irvine and Gal's perspective, Dhaouadi has had to "ignore or minimize" the reality of his own observations to make such metonymous distinctions.

Such ideologies never emerge from nowhere. They, too, have histories, and to recall Renan's observation about nationalism, these histories are generally forgotten, recalled in error, or, in many cases, unknown. There is, of course, the history of women's access to education in Tunisia, an issue Dhaouadi mentions in passing but does not investigate to any degree. There is also the issue of 
complex link of French with urbanity, something noticed by Trabelsi but not Dhaouadi. Likewise, there is the settlement history - to use an apt construct from traditional dialectology - of Tunis, the changing demographics of the city and the surrounding suburban areas, and the changing nature of face-toface interactions, things reminiscent of Massignon's notion of foyer.

Further, as noted, Dhaouadi himself seems much influenced by the work of Memmi - and we can certainly assume he is familiar with the work of writers like Fanon and other who theorized about the North African situation - and by the early work of Trudgill. (Apparently, he was unaware of the responses or research Trudgill's initial discussion of gender and prestige gave rise to.)

Yet, fully appreciating the local meanings of Dhaouadi's claims requires knowledge of the local context, specifically, knowledge of the nature of national identity as understood by Tunisians. In the next section of this paper, I seek to link the ideologies that gender French and hence Arabic with other, larger dichotomies of Tunisian daily life.

The particulars in Tunisia, represented schematically, are given in Table 2. The poles of debates related in any way to questions of national identity -

Table 2. Discursive dichotomies constitutive of Tunisian national identity

\begin{tabular}{|c|c|c|}
\hline Arabic term & așaala & 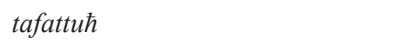 \\
\hline Meaning & $\begin{array}{l}\text { firmness, steadfastness, strength of } \\
\text { character; nobility of descent, } \\
\text { purity of origin. }\end{array}$ & $\begin{array}{l}\text { openness, receptivity (spiritual, } \\
\text { mental). }\end{array}$ \\
\hline Derivation & $\begin{array}{l}\text { Verbal noun derived from the verb } \\
\text { așula: to be or become firmly } \\
\text { rooted; to be firmly established; to } \\
\text { be of noble origin. }\end{array}$ & $\begin{array}{l}\text { Verbal noun derived from the verb } \\
\text { tafatta } \hbar \text { : to open, open up, } \\
\text { unfold (intr.); to be opened ...; } \\
\text { to be open, responsive (heart). } \\
\text { (Wehr 1974: } f-t-\hbar)\end{array}$ \\
\hline $\begin{array}{l}\text { Lexical items } \\
\text { derived from } \\
\text { the same root }\end{array}$ & $\begin{array}{l}\text { Lexical items derived from } a-s-l \text { : } \\
\text { root, trunk (of a tree); origin, } \\
\text { source; inception; cause, reason; } \\
\text { descent, lineage, stock (esp. one } \\
\text { of noble character); foundation, } \\
\text { fundament; basis; the original } \\
\text {. . . ; original work; așlii: original, } \\
\text { primary, primal, initial; genuine, } \\
\text { authentic, pure; basic, } \\
\text { fundamental, principal, chief, } \\
\text { main; regular; real, actual ... luya } \\
\text { așliyya mother tongue. (Wehr } \\
\text { 1974: } a-s-l \text { ). }\end{array}$ & \\
\hline $\begin{array}{l}\text { French translation } \\
\text { equivalent }\end{array}$ & authenticité & ouverture \\
\hline English gloss & 'authenticity' & 'openness' \\
\hline
\end{tabular}


whether the proper role of Arabic or French in education, the proper nature of Islam, or proposed changes to laws about women and families in society - are often framed in terms of the dichotomy contrasting asaala, an Arabic term rendered into French as authenticité, with tafattuћ, an Arabic term rendered into French as ouverture. ${ }^{13}$ For simplicity, I'll refer to the dichotomy as authenticity and openness. Table 2 gives information about the semantic fields associated with the Arabic terms.

As linguists would expect, the mapping from Arabic to French, typologically distinct languages, is by no means perfect, an observation made and exploited in an important essay by one of Tunisia's finest thinkers, Abdelwaheb Bouhdiba (1995), "Des difficulties d'être soi-meme: Açala-authenticité" [The difficulties of being oneself: . . . ], which examines the slippage between the Arabic term and its French "equivalent", exploiting it masterfully. (Such bilingual slippage is a reality Tunisians live with daily.) Significant here, however, are the facts that, first, Tunisians generally value both of these qualities highly while at the same time fully acknowledging the tension between them and, second, each of these poles is further linked to a series of other values, setting up more of the analogies of the sort Dhaouadi assumed.

We can analyze these dichotomies, which become parts of analogical chains of identity, in terms of iconization of some social phenomenon, fractal recursivity, and erasure. Figure 6 lists some common contrasts one finds evidence of in Tunisians daily discourse, whether casual conversation or academic debate. Large sections of Abbasi (2005) are devoted to commenting on the first four of these although, as explained in note 12, he framed the first pair as "authenticity" and "modernity". The lexicon of Tunisian Arabic can be said to reflect aspects of these dichotomies as well. For example, speakers distinguish between an Arab houses built around a courtyard, dar Sarabi 'Arab house', and a "villa", a European (=French)-style house that is not; between "Arabic" carrots fed to animals and "French"14 carrots eaten by people, and between

așaala/authenticité

Arabic

The Muslim world

Tradition tafattuћ/ouverture

French

The West

Modernity

Self $\quad$ Other

Male

Female

Figure 6. Linking the dichotomies in Table 1 to other dichotomous pairs of values that constitute Tunisian discourse 
"Arabic" toilets (called "Turkish" or "squat toilets" in the US), and "French" toilets. In a profound sense, these dichotomies and their reflexes encode the consequences of the colonial experience.

From such a perspective, in contrast to French, Arabic is authentic. We should not be surprised to find authenticity and Arabic linked to Islam and the Muslim world or to tradition, especially as they contrast with openness, which is linked to French, the West more broadly, progress, and modernity. Yet, as might be expected, such dichotomies contain the seeds of contradiction. Thus, while Arabic is authentic in contrast to French, in a different situation, Tunisians will quickly admit that Tunisian Arabic, the national dialect and everyone's native language, is in some sense more "authentic" than Modern Standard Arabic, which is learned at school - just the sort of ideological move Ferguson (1959) taught us to predict about diglossia. This slippage is significant. It helps us understand how and why Tunisians come to see authenticity as self and openness as other in some contexts, though both qualities are valued. It also enables us to see why Dhaouadi in particular and Tunisians more generally, even educated Tunisian women like Trabelsi, sometimes end up identifying the constellation of things often associated with authenticity as male and those often associated with openness as female.

Such an ideologization takes place even though in Tunisia, as elsewhere, one can point to many ways in which just the opposite seems to be the case. For example, Tunisian men certainly took up Western dress long before Tunisian women did. Women there continue to be more likely to wear traditional clothing, and when they do, its meanings are often different than when Tunisian men wear it. Although Tunisian law states that men and woman can marry whom they please, custom dictates that Muslim Tunisian men may marry outside their faith while Muslim Tunisian women cannot. And finally, Tunisian females were and in some ways continue to be protected - if not sequestered - from participation in the world outside the home, the community, or the nation. (In these cases, Tunisian women, like women in many cultures, are or are seen as bearers of traditional or authentic culture.)

As I have noted, the dichotomies I have presented are the dominant ones seen from and through the dominant ideology, one that is - and continues to be - overwhelmingly male as is likely the case worldwide. It is important to note that Tunisian women enjoy legal rights of many sorts not enjoyed by their Muslim sisters across the Arab world because issues related to personal status — and therefore marriage and the family — are issues decided in civil rather than religious courts. Yet even historians of the women's situation in Tunisia explicitly state or imply that they have those rights largely because of the decisions and actions of men, especially Habib Bourguiba, Tunisia's first president, and more recently, President Zine El Abidine Ben Ali (e.g., Charrad 2001; Marzuki 1993). 
Such a situation might lead some to claim that in contrast to women, or at least educated women, who construct their nation-state as modern, men (and by default, uneducated women) construct it as authentic. Yet, such an analysis is too simple. A more nuanced reading of these dichotomies might argue that many educated women and male political "liberals", and I use the term advisedly, assume both poles of the dichotomy are important and that they can coexist in tension productively. ${ }^{15}$ Indeed, it is the tension that produces much that is uniquely Tunisian in the eyes of this group of Tunisians.

Such a view was surely that of the early leaders of the Tunisian state, men who had generally received bilingual educations, most often at the Collège Sadiki, as noted. These men were fully comfortable speaking French, often having received their higher education in France. In using French well - and often by adhering to prescriptive norms no longer in common use among native speakers in the metropole with regard to syntax or morphology (e.g., the use of the imparfait du subjonctif), these leaders demonstrated their mastery of the French language and the culture associated with it. Yet when they spoke French, they generally did so with an accent that was unmistakably North African, however heavy or light. Their phonology enabled them to convey a different message, a loyalty to their North Africanness that exclaimed: "I may have become a master of your language, but you have not become the master of my soul." Thus their use of French represented an interesting case of Bakhtinian double-voicing, one that assuredly occurs with great frequency in many bilingual speech communities.

To the extent that I am correct in my analysis of this often strongly accented French, we might ask whether, instead of imitating the native speakers of standard French with respect to accent, as Dhaouadi contended Tunisian women do, Tunisian women are not merely (or at least also) distinguishing themselves from Tunisian men, who have defined themselves symbolically in contrast to the now-former colonizer. Further, they are doing so in a culture where there is near universal acceptance of the ideology of gender complementarity. Given the nature and power of gender complementarity and Tunisia's history, we might wish to argue that the ideologies discussed in this article are overdetermined.

What should be clear is that Tunisian women and men are positioned differently in and by these ideologies. Thus, the same behavior when performed by a female or male is valued and evaluated differently. In an important way, then, Tunisian women, through their knowledge and use of French, are left dépaysées in their own country. In other words, the ideologies and chains of metonymic reasoning sketched here symbolically locate them outside the nationstate. Specific instances of the use of French and particularly the evaluations and social meanings of these uses of French are further complicated by variables like amount and kind of education, class and region of origin and residence, and even political orientation of the listener even more so than that of 
the speaker. The situation becomes yet more complex when we acknowledge the variable nature of many such behaviors and evaluations of them.

As Irvine and Gal noted, "when such oppositions", by which they mean the sorts of dichotomies analyzed in this paper, "are reproduced within a single person, they do not concern contrasting identities so much as oppositions between activities or roles associated with prototypical social persons" (Irvine and Gal 2000: 38). Ochs (1992), of course, argued that indirect indexicality, perhaps the most powerful symbolic and ideological work done by and through language, is most often associated with acts, activities and stances. All three scholars pointed to the fact that ideologies are created and reproduced not through broad categories like gender but through specific repeated activities, roles, acts, and stances that come to be gendered across time in particular historical contexts. Scholars like Bourdieu (1990) or Butler (1993) who focus on the habitus and performativity, respectively, might make similar observations from a slightly different perspective. Thus, it is here that we should seek to understand the origins of ideologies, whether they concern language or some other social phenomenon.

\section{Conclusion}

I began this paper hoping to shed light on three sets of related issues, the presence of French in Tunisia, its gendered social meanings, and ideologies associated with those meanings. Along the way, I have discussed a range of topics that bear on these issues: the demographics of languages in Tunisia; the nature of the Tunisian population, especially the "European" population and its location during the colonial period; and the implicit logic as well as the internal contradictions of Tunisian ideologies of language and gender as they relate to and construct French and Arabic. Importantly, I would contend, I have sought to begin historicizing these phenomena so that we might have a better understanding of how they came to be.

While my focus has been the construction and linking of femininity and French by Tunisians, I have indirectly been constructing the links found there between masculinity and Arabic, even as I raised questions about the nature of nationalism in Tunisia and for Tunisians. Though Tunisians often contrast Arabic and French, my observations near the end of my analysis make clear that a more accurate formulation of the contrast might be a more profoundly structuralist one: monolingual Arabic or not monolingual Arabic, which in Tunisia often becomes Arabic/French bilingualism, including Arabic/French codeswitching. Although such an account favors social structures over the agency of individuals, I have also sought to demonstrate ways in which Tunisian women, in particular, positioned by these ideologies, find room for agency 
even when doing so results in their being criticized for being inauthentic in some way - not being Tunisian enough or being too French or European. At some level, such charges are predicated on a nineteenth-century view of language and nationalism that Westerners, at least, see as unproblematically linking a language, a people, and a nation (or nation-state) in ways that rarely, if ever, correspond with what we might term the reality on the ground (cf. note 11).

Over the years, in discussing the relationships that I understand Tunisian men and women to have with French and Arabic as well as the ways in which these relationships are ideologized, I have sometimes found that my interlocutors find the situation I describe most unusual, if not bizarre. From my perspective, nothing could be further from the truth. In surveying Anglophone university students in Lebanon, Diab (2000) found that both female and male students expected females to be speak English and/or French better than males and to have a more native-like accent when they doing so. During the years that I taught doctoral students at the University of Texas (1991-2006), I often found that females from a range of countries, more than males from the same countries, were likely interested in speaking their primary foreign language, English, with accents that marked them less obviously as to place of origin. In a goodly number of cases, as with South Korean men speaking English, the lack of interest in "having a good accent" seems to be related to overlapping constructions of masculinity and nationalism: a Korean man who speaks English without a marked Korean accent is perceived by other Koreans, female and male, as being not quite manly and not quite Korean. Closer to home, the way that Western sociolinguists have sometimes been quick to label women's use of standard forms or engaging in Labovian hypercorrection as evidence of linguistically insecure while the behavior of men who use nonstandard forms or stigmatized variants is analyzed in terms of covert prestige shows interesting parallels with the Tunisian situation: women's behavior is framed as somehow deviant without acknowledgment of the ways in which such labeling simultaneously positions men's behavior as the norm.

In such cases, men's use and understanding of the use of languages other than the native one might be seen as utilitarian. Symbolically, it can be linked to an imagined status quo that is, in fact, a nostalgic longing for a past less characterized by heterogeneity than the present moment. In contrast, women's use and understanding of the use of languages other than the native one can be seen as an effort to shift the currency of the society's symbolic economy. (In these cases, linguistic skill comes to represent a resource for a woman who possesses it as well as those with whom she is associated.) Such tendencies with regard to the nature of the past and the future and such competing visions of authenticity can be found in all societies. Interestingly, in the situations described here, each position comes to be gendered through language. 
From a different perspective, I would note that during the early 1990s, when I regularly taught courses on African American English, again at the University of Texas at Austin, I repeatedly found that the African American women in my course defined Standard English as "talking proper" while the African American males defined it as "talking white". Here, yet again, we see a gendering of a language variety by members of a speech community, one that assuredly has consequences for the speech community and American society at large. In such a sociohistorical context, what self-respecting African American male would wish to be seen as a user of Standard English?

Whatever the consequences of such gendered language ideologies and whatever historical circumstances might have given rise to them, I trust these anecdotes demonstrate that we, as analysts, are safe in assuming that gendered language ideologies are widespread and in no sense limited to Tunisia, the Arab world, or the developing world more broadly. Understanding them in their complexity will require that we pay attention to the social history of languages and language varieties in the speech communities we study, drawing on many sorts of sources, ranging from ethnographic fieldwork to census data to the joke with which I began this paper.

Portland State University

Correspondence address: waltersk@pdx.edu

\section{Notes}

* This paper grows out of talks I have given over the past decade in a range of settings including conferences in Tangier, Morocco (2001), Lancaster, UK (2002), Berkeley (2003) and UT-Austin (2003) as well as lectures at Rice University (2004) and Portland State University (2006). I am deeply grateful for the comments from audience members in all these settings that have led me to think about the complex issues discussed in this article in new ways. Thanks also to Jonathan Tamez for his insights into the situation described here.

1. While studying with Joel Sherzer in the early 1980s, I heard him remark that if he had a single afternoon in which to collect data in order to understand a culture, he would ask its members to tell him jokes, which, upon analysis, would reveal much of importance about the culture's social organization and values. They would do so precisely by revealing the fault lines within the society as well as the ideologies that have been created to naturalize categories of social difference.

2. Within the framework of Myers Scotton (1993), one could analyze both of these switches as marked. "Local anesthetic" could be seen as a cultural borrowing although it has an equivalent in Modern Standard Arabic (MSA). We can safely predict that younger Tunisians, having received far more of their education in Arabic than the woman in the joke or those retelling the joke in the 1980s, would be more likely to use an Arabic expression here were they telling this joke today. (Of course, using an expression originating in MSA here would mean the loss of any implicatures associated with use of a French term for something associated 
with modern medicine.) I can attest that many lexical items and expressions of French or Italian origin that I learned in the 1970s as a student of Tunisian Arabic have been replaced by their MSA equivalents at least among younger speakers. "Imported" is not merely a marked switch; it is iconic in some crucial sense, laminating language choice and the ideology being held up to ridicule: anything imported is better than anything local.

3. With respect to the phonology used for renditions of "La Marsa" in contrast to its Arabic equivalent, it is important to note that, as in codeswitching generally, the choice of a lexical item — including the rendering of a geographic place name - may serve one or more interactional, rhetorical, or social functions while the phonology used to pronounce it serves others. Further, when retelling this joke, men who generally spoke French with a North African accent sometimes used an accent much closer to the one associated with Standard French. In so doing, they were heard as mocking those whose French was closer to the prescriptive standard - imported — rather than the local variety (cf. Chun 2004).

4. This term also shows up in French expressions as diverse as "source of heat", "seismic focus", "center of an infection", "hotbed of corruption", "broken home", "return to one's native land", "student center" and "focus of a lens" (Mansion et al. 1980: q.v.).

5. See Walters (2007a) for additional detail on these data and for charts illustrating the demographics of the languages of literacy in Tunisia for females and males in 1984. As best I can determine based on the available electronic information, questions about languages read and written were not asked in the more recent 2004 census. An obvious truth should be restated here: census data are inherently problematic, but they are often the best data available for discussions of language at the national level.

Worth noting in this context is the fact that whereas the results of the 1994 census were published in French, the results of the 2004 census were published in Arabic (though some information about the results is published online in French - these data are available under "Publications en ligne" at http://www.ins.nat.tn/indexen.php).

6. A similar situation holds in many countries colonized by the European powers. During the colonial period, access to the colonial language was limited to an elite among the colonized; stated differently, by learning the colonial language, those who were colonized could aspire to elite status in new ways. Following the colonial period, policies that envisioned universal education mandated education in the language of the colonizer generally because there was a lack of teachers ready to teach in the local language(s) as well as a lack of materials for them to use in teaching. (In many multilingual countries, the language of the former colonizer was chosen as a "neutral" national language, whether or not it was granted official status, in an effort to mitigate pre-existing interethnic tension.) Thus access to schooling, coupled with population growth (even in countries like Tunisia, where family planning has been strong since the 1960s), ensured the growth in the number and percentage of the population that spoke the language of the former colonizer.

7. In contrast to Algeria, officially part of France from 1848-1962, where Sephardic Jews ("les israélites indigènes de l'Algérie") were granted French citizenship in 1870 by the Décret Crémieux, local Jews in Tunisia, a French colony from 1881-1956, and Morocco, a French protectorate from 1912-1956, were never as groups offered French citizenship. The decree also offered Algerian Muslims French citizenship; however, they had to request it and agree to live by French laws, thus giving up any rights to be subject to the Islamic legal system. In contrast to Algerian Jews, Algerian Muslims had no interest in forsaking the Islamic legal system.

8. Obviously, categories related to sexuality and sexual behavior are culturally constructed. Traditionally and perhaps predictably in a culture that has practiced sex segregation to a degree unknown in the West and that has fetishized female virginity at marriage, merely participating in sexual intercourse involving two males has been far less stigmatized than taking 
the role of the so-called passive partner, a situation that in many ways parallels attitudes toward male same-sex intercourse and homosexual behavior more broadly in the cultures of Latin America.

9. It is also worth noting that in gendering the pronunciation of $/ r /$ when speaking French as Tunisians and North Africans generally do, people in these countries are assigning new symbolic meanings to a practice that was and remains ideologically laden among native speakers of French in France. There, the use of the apical variant represents a categorical regional dialect feature, a quantitative class-based distinction, and a quantitative gender-based distinction. Thus, regional dialects where $[\mathrm{B}]$ is the variant used are generally the overtly prestigious ones. Within social classes in a given geographic area, those of the educated classes are more likely to use $[\mathrm{b}]$ than $[\mathrm{r}]$, and within a social class, women are more likely to use $[\mathrm{K}]$ than $[\mathrm{r}]$. Such facts remind us of the contingent nature of language ideologies and the need for an understanding of the social history of languages and language varieties. In fact, many of these observations, along with other relevant ones, can be found in the discussion included as part of Riahi (1968).

10. I found the two unpublished manuscripts in the library of CEMAT, the Centre d'Etudes Maghrébines à Tunis. My comments should not be taken as an ad hominem; rather, as the citation of Dhaouadi's 1984 article by Trabelsi (1991) demonstrated, his comments represent perspectives quite common among Tunisians from many backgrounds, my interest here.

11. The stigmatization of codeswitching obviously represents a particular form of (monolingual) language purism. In the West, it can easily be linked to ideologies associated with standard varieties and standardization (e.g., Lippi-Green 1997), themselves part of European nationalism and its history, where a people, a language, and a land are seen as indivisible. From this perspective, codeswitching must be evaluated negatively, whether the codeswitcher is seen as switching because of lack of mastery of one or both of the languages or a lack of loyalty to the language (or nation linked to the language) from which the speaker switches.

A bilingual perspective on codeswitching might question why bilinguals, when interacting, would avoid switching, an approach pursued to some extent by Myers Scotton (1993). From this perspective, asking a bilingual not to codeswitch when interacting with someone who shares the same languages and similar language abilities is like asking an able-bodied person to swim using only one arm and one leg.

12. Worth considering is the extent to which such dichotomies might be a function of human perception and cognition and the degree to which such dichotomies are encouraged by structural considerations. As noted, one of the ways Tunisia differs from its Maghrebian neighbors is the absence of a sizeable population of citizens who identify as Berber or speak a variety of the language. Thus, although one finds similar genderings of French in Algeria and Morocco, the local details differ in crucial ways because of the presence of larger Berber minorities and the particular histories of each country.

13. In a most provocative book, Abbasi (2005) formulated this dichotomy in terms of the Arabic and French equivalents of "authenticity" and "modernity" (Ar. hadaatha), rather than "openness", noting that the distinction dates to the nineteenth century (Abbasi 2005: 43) while Bouhdiba (1995), citing the writing of reformer Khéreddine Pacha (1822-1890), set up the distinction as one between "authenticity" and "renewal" (Ar. tajdid, Fr. renouveau). Abbasi also often used dichotomies to explicate aspects of Tunisian identity, Tunisian history, and perspectives on both. Throughout his book, readers find clear direct and indirect evidence of the robustness of these dichotomies and the ways in which they continue to shape discussions of Tunisian identity in numerous ways. Likely because his concern is history and historiography as reflected in school texts on Tunisian history, he does not mention issues of gender at all. Thus, like many historians, especially earlier ones, the historical subject or citizen is genderless or more likely assumed to be male. 
14. In these cases, the most dialectal of the Tunisian Arabic terms used for "French" (adj.) is souri (as it would be transliterated into French), the etymology of which is unknown. It is also the term traditionally used for the French language; thus, titkellem bsouri translates as 'you (sg.) speak [with] French'.

15. Cf. Zamiti-Horchani (1986) and my discussion of it in Walters (1999). Although I fully expect the percentages associated with categories to have shifted since Zamiti-Horchani's survey, I would expect that the social categories or subject positions she described likely remain in many ways unchanged.

\section{References}

Abbasi, Driss. 2005. Entre Bourguiba et Hannibal: Identité tunisienne et histoire depuis l'Independence. Paris: Karthala \& Aix-en-Provence: IREMAM.

Bakalti, Souad. 1996. La femme tunisienne au temps de la colonisation 1881-1956. Paris: L'Harmattan.

Bouhdiba, Abdelwahad. 1995. Des difficultés d'être soi-même: Açala-authenticité. In Quêtes sociologiques: Continuités et ruptures au Maghreb, 60-73. Tunis: Cérès Éditions.

Bourdieu, Pierre. 1987. Distinction: a social critique of the judgment of taste. Richard Nice (trans.). Cambridge: Harvard University Press.

Bourdieu, Pierre. 1990. Language as symbolic power. Gino Raymond \& Matthew Adamson (trans.). Cambridge: Harvard University Press.

Brahim, Ahmed. 1994. Linguistique contrastive et fautes de français. [Publications de la Faculté des lettres de la Manouba, Série: Linguistique, Volume VI] Tunis: Imprimerie Officielle de la République Tunisienne.

Butler, Judith. 1993. Bodies that matter: on the discursive limits of sex. New York \& London: Routledge.

Charrad, Mounira. 2001. States and women's rights: the making of postcolonial Tunisia, Algeria, and Morocco. Berkeley: University of California Press.

Chun, Elaine. 2004. Ideologies of legitimate mockery: Margaret Cho's revoicings of Mock Asian. Pragmatics 14. 263-289.

Daoud, Mohammed. 2001. The language situation in Tunisia. Current Issues in Language Planning 2. 1-52.

Dhaouadi, Mahmoud. 1984. Des racines du franco-arabe féminin au Maghreb. Arab Journal of Language Studies (Institut International de langue arabe de Khartoum, ALESCO) 2. 145-162.

Dhaouadi, Mahmoud. n.d.a. Into the roots of the difference in the French Parisian accent use among Tunisian women and men. (Unpublished manuscript written between 1992 and 1997.)

Dhaouadi, Mahmoud. n.d.b. Tunisian women's strained social status as reflected in the verbal discourses of adàà and Franco-Arabe. (Unpublished manuscript written between 1991 and 1997.)

Diab, Rula. 2000. Lebanese students' beliefs about learning English and French: a study of university students in a multilingual context. University of Texas at Austin, unpublished dissertation.

Dornier, François. 2000. Les Catholiques en Tunisie au fils des ans. Tunis: L'Imprimerie Finzi.

Ferguson, Charles. 1959. Diglossia. Word 15. 329-340.

Institut Nationale de la Statistique. 1997. Recensement général de la population et de l'habitat de 1994: Caractéristiques d'éducation, tableaux statistiques [Preliminary internal report], Mimeo. Tunis: République Tunisienne, Ministère du Développement Économique.

Institut Nationale de la Statistique. Recensement de la population 2004. http://www.ins.nat.tn/ indexfr.php (accessed July 25, 2011). 
Irvine, Judith. 1989. When talk isn't cheap: language and political economy. American Ethnologist 16. 248-267.

Irvine, Judith \& Susan Gal. 2000. Language ideology and linguistic differentiation. In Paul Kroskrity (ed.), Regimes of language: ideologies, polities, and identities, 35-83. Santa Fe: School of American Research.

Kroskrity, Paul V. 2004. Language ideologies. In Alessandro Duranti (ed.), A companion to linguistic anthropology, 496-517. Malden, MA: Blackwell.

Lippi-Green, Rosina. 1997. English with an accent: language, ideology, and discrimination in the United States. London and New York: Routledge.

Machuel, Louis. 1906. L'Enseignement public en Tunisie (1883-1906). Tunis: Société Anonyme de l'Imprimerie Rapide.

Mansion, J. E., D. M. Ledesert \& R. P. L. Ledesert. 1980. Harrap's Standard French and English dictionary. London: Harrap.

Marçais, William. 1938. Comment l'Afrique du Nord a été arabisée. Annales de l'Institut d'Études Orientales (Faculté des Lettres de 1'Université d'Alger) 4. 1-22.

Massignon, Louis. 1924. Éléments arabes et foyers d'arabisation: Leur rôle dans le monde musulman actuel. Revue du Monde Musulman 57. 1-157.

Marzuki, Ilhem. 1993. Le mouvement des femmes en Tunisie au XXème siècle. Tunis: Cérès Productions.

Memmi, Albert. 1957. Portrait du colonisé, précédé du portrait du colonisateur. Paris: Payot.

Myers Scotton, Carol. 1990. Elite closure as boundary maintenance: the evidence from Africa. In Brian Weinstein (ed.), Language policy and political development, 25-41. Norwood, NJ: Ablex.

Myers Scotton, Carol. 1993. Social motivations for codeswitching: evidence from Africa. Oxford: Oxford University Press.

Ochs, Elinor. 1992. Indexing gender. In Alessandro Duranti \& Charles Goodwin (eds.), Rethinking context: language as an interactive phenomenon, 336-358. Cambridge: Cambridge University Press.

Perkins, Ken. 2004. A history of modern Tunisia. Cambridge: Cambridge University Press.

Riahi, Zohra. 1968. Le français parlé par les cadres Tunisiens. Revue Tunisienne de Sciences Sociales 13 [Actes du 2ème Séminaire du Linguistique, 12-14 avril 1967]. 195-217.

Sherzer, Joel. 2002. Speech play and verbal art. Austin, TX: University of Texas Press.

Sraïeb, Noureddine. (n.d.) Le Collège Sadiki de Tunis: 1875-1956, Enseignement et nationalisme. Tunis: Alif.

Trabelsi, Chedia. 1991. De quelques aspects du langage des femmes de Tunis. International Journal of the Sociology of Language 87. 87-98.

Trudgill, Peter. 1972. Sex, covert prestige and linguistic change in the urban British English of Norwich. Language in Society 1. 179-194.

Walters, Keith. 1996. Language, gender, and political economy: anglophone wives in Tunisia. Language in Society 26. 515-556.

Walters, Keith. 1999. "Opening the door of paradise a cubit": educated Tunisian women, embodied linguistic practice, and theories of language and gender. In Mary Bucholtz, A. C. Liang \& Laurel A. Sutton (eds.), Reinventing identities: the gendered self in discourse, 200-217. Oxford: Oxford University Press.

Walters, Keith. 2006. Communal dialects. In Kees Versteegh, Mushira Eid, Alaa Elgibali, Manfred Woidich, \& Andrzej Zaborski. (eds.), Encyclopedia of Arabic language and linguistics, Vol. I, 442-448. Leiden: Brill.

Walters, Keith. 2007a. Considering the meanings of literacy in a postcolonial setting: the case of Tunisia. In Beth Daniell \& Peter Mortensen (eds.), Women and literacy: local and global inquiries for a new century, 189-206. New York: Lawrence Erlbaum and Associates \& Urbana, IL: National Council of Teachers of English. 
Walters, Keith. 2007b. Language attitudes. In Kees Versteegh, Mushira Eid, Alaa Elgibali, Manfred Woidich, \& Andrzej Zaborski. (eds.), Encyclopedia of Arabic language and linguistics, Vol. II, 650-664. Leiden: Brill.

Walters, Keith. 2011. Education for Jewish girls in late nineteenth- and early twentieth-century Tunis and the spread of French in Tunisia. In Emily Benichou Gottreich \& Daniel Schroeter (eds.), Jewish culture and society in North Africa, 257-281. Bloomington, IN: Indiana University Press.

Wehr, Hans. 1974. A dictionary of modern written Arabic (Arabic-English), 4th ed. J. Milton Cowan (ed.). Ithaca, NY: Spoken Language Services.

Zamiti-Horchani, Malika. 1986. Tunisian women, their rights, and their ideas about their rights. In Monique Gadant (ed.), Women of the Mediterranean, 110-119. London: Zed Books.

Zangar, Selwa Khaddar. 1997. Une école pionnière, l'école de la rue de Pacha. In La femme tunisienne à travers les âges, 176-180. Tunis: Institut National du Patrimoine. 
Copyright of International Journal of the Sociology of Language is the property of De Gruyter and its content may not be copied or emailed to multiple sites or posted to a listserv without the copyright holder's express written permission. However, users may print, download, or email articles for individual use. 